\title{
La amenaza fantasma: \\ El virrey Pezuela frente a la Expedición \\ Libertadora (1818-1820)
}

\section{The Phantom Menace: Viceroy Pezuela against the Liberating Expedition (1818-1820)}

Patricio A. Alvarado Luna ${ }^{1}$

Universität zu Köln

\section{Resumen}

Tras la batalla de Maipú en 1818, el siguiente paso en el plan de San Martín para asegurar la independencia fue dirigirse al Perú. Para esto, se formó un plan que tomó casi dos años en concretarse: la Expedición Liberadora. Durante este tiempo, desde el virreinato peruano, el virrey Pezuela, temeroso de su arribo, organizó diversas medidas defensivas para Lima y la costa. Este temor generó un miedo colectivo y diversos cuestionamientos al virrey. El presente artículo analiza,

1 Licenciado (2014) y magíster (2017) en Historia por la PUCP. Actualmente, se encuentra culminando sus estudios doctorales en Historia Ibero-Latinoamericana en la Universidad de Colonia, Alemania. Se ha especializado en la historia política, social y militar del primer tercio del siglo XIX hispanoamericano, con énfasis en el proceso de independencia, en la formación de los Estados y en la Confederación Perú-boliviana, sobre la cual trabaja en su tesis doctoral. Ha publicado investigaciones acerca del Gobierno del virrey Pezuela y la independencia del Perú; su primer libro es Virreyes en armas. Abascal, Pezuela y La Serna: la lucha contrarrevolucionaria desde el virreinato del Perú (1808-1826) (2020). Correo: patricio.alvaradol@pucp.pe; ORCID: 0000-0001-7064-3392. 
centrándose en la Memoria de Pezuela, la situación virreinal desde los primeros rumores de la formación de la Expedición Libertadora en 1818 hasta su arribo en 1820.

Palabras clave: Expedición Libertadora; Pezuela; San Martín; Trienio Liberal; Thomas Cochrane

\section{Summary}

After the battle of Maipu in 1818, the next step in San Martín's plan to ensure independence was to head to Peru. For this, a plan was formed that took almost two years to complete: The Liberating Expedition. During this time, from the Peruvian viceroyalty, Viceroy Pezuela, fearful of his arrival, made various defensive measures for Lima and the viceregal coast. This fear generated a collective fear and various questions to the viceroy. This article analyzes, focusing in the Memoria of Pezuela, the viceregal situation from the first rumors of the formation of the Liberating Expedition in 1818 until its arrival in 1820 .

Key Words: Liberating Expedition; Pezuela, San Martín; Liberal Triennium; Thomas Cochrane

\section{Introducción}

132 "Se perdió la batalla de Maypú; se destruyeron las esperanzas quiméricas de colocar a Osorio de presidente de Chile [...]. Vergüenza, señor, causa decirlo" (Torata, 1894, p. 27). De esta manera se refirió el teniente general Jerónimo Valdés a la consolidación de la independencia de Chile en 1818 a manos de las fuerzas militares de José de San Martín. Tras casi ocho años de conflictos, conquistas y reconquistas, el 5 de abril de 1818 , las fuerzas realistas fueron derrotadas en los campos de Maipú. Tan solo unos meses atrás, el virrey del Perú, Joaquín 
de la Pezuela, había puesto todas sus esperanzas y esfuerzos en los planes para esta "reconquista" (Basadre, 1973, p. 151), por lo que las críticas, tanto de la población de Lima como de los mismos generales realistas en la ciudad y en el Alto Perú, no se hicieron esperar.

La historiografía de la independencia, hasta hace poco, ha mostrado un exiguo interés en el estudio del Gobierno del virrey Joaquín de la Pezuela. Ya en 1950, De la Puente Candamo había advertido que "la época incierta de su mando, el final revolucionario y la escasa investigación de documentos originales, provocan un evidente alejamiento de la historiografía nuestra frente al tema de Pezuela" (De la Puente Candamo, 1971, p. 239). Este desinterés llama la atención, pues desde la publicación de su Memoria de Gobierno en 1947 (editada bajo ese nombre, pero la cual es, en realidad, un diario), Rodríguez y Lohman Villena (sus editores) consideraron al Gobierno del virrey Pezuela como "una espada limpia $y$ temible en manos de un jefe a quien reconoce el poder de la última decisión”, a lo cual agregan que su mérito radicó en buscar retener el dominio español en el Perú pese a luchar "contra fuerzas superiores [...] porque nada podía a la verdad hacer un hombre solo para repeler los ataques de todos los flancos" (1947, p. XIV, XXIV y XXX). Siguiendo esta línea de interpretación, De la Puente Candamo destacó una imagen positiva y benevolente del virrey, al considerar que, durante su Gobierno, alentó esperanzas de triunfo, y trabajó con tenacidad y constancia en la preparación de la defensa del Virreinato (1948, p. 8 y 1971, p. 247).

Posiblemente este desinterés se debe a la interpretación de Anna sobre el Gobierno de Joaquín de la Pezuela, quien lo consideró como "una serie de derrotas" tras la independencia de Chile y presenta al personaje como un poco ingenuo frente a los acontecimientos, especialmente en lo referente a la reconquista de Chile: "El gobierno de Pezuela se inició 
así, con la pérdida de Chile; se vio marcado por la tragedia personal, y terminó con su derrocamiento por los oficiales principales del ejército en enero de 1821. El régimen realista iba de catástrofe en catástrofe, mientras que los signos de apoyo popular por la independencia comenzaron a aparecer en Lima” (2003, p. 185). A esto se puede agregar la interpretación de Fisher, quien lo juzgó incapaz de defender los virreinatos de Perú y Chile de las fuerzas de San Martín (2000, pp. 198-199). Los recientes trabajos de Albi de la Cuesta (2009), Peralta Ruiz (2010), De la Puente Brunke (1998 y 2012), Alvarado Luna (2014, 2015a, 2015b, 2017 y 2020) y Martínez Riaza (2014 y 2016) han buscado cambiar esta percepción. Por otra parte, dentro de los estudios sobre el miedo durante este período -tema central en el presente artículo- destacan los de Claudia Rosas (2005) y, sobre este tema en concreto, como una primera aproximación, el trabajo de Cristina Mazzeo sobre la familia Lavalle (2005).

Es importante destacar que el estudio del miedo durante estos años está vinculado con los rumores y con la duda de su veracidad. Así, según Delameau, "un rumor es un caldo de cultivo de miedo reprimido; el resultado de un proceso de desarrollo deliberado que se inició al concentrar amenazas o circunstancias adversas" (1985, p. 245). Siguiendo esta línea, Fernando Rosas ha destacado la necesidad incorporar en la naturaleza del miedo "la noción de seguridad, pues en el deseo fundamental de alcanzar ese estado tanto el individuo como las sociedades se encuentran en una tensión que la realidad, a través de múltiples manifestaciones, convierte en inseguridad" (2005, p. 24). Por su parte, Claudia Rosas ha estudiado el rol del rumor en la propagación del miedo. Para ella, "el temor trabajaba no solo en los espacios a los que llegaba la información sino también sobre la base de comentarios, especulaciones y rumores generados por la carencia de noticias o la información fragmentaria que los habitantes del virreinato tenían a su disposición” (2005, p. 143). 
Siguiendo esta línea, el presente artículo tiene como objetivo desterrar la visión que describe al Gobierno del virrey Pezuela como incapaz y como una simple bisagra entre los Gobiernos de Abascal y La Serna; para ello, nos centraremos en las medidas que llevó a cabo desde 1818 tras los primeros rumores de la Expedición Libertadora. Para esto, y tomando como base principal la Memoria de Gobierno de Pezuela, dividiremos el trabajo en tres secciones principales. En la primera, se analizan los rumores iniciales que llegaron a Lima sobre la formación de la Expedición Libertadora, a la par que se explican los avatares de San Martín y del Gobierno chileno para su formación. En la segunda sección, se desarrollan las correrías de Thomas Cochrane en el litoral virreinal peruano y las medidas adoptadas por el Gobierno para contener los diversos ataques. Finalmente, en la última sección, se analizan los efectos de la llegada de la Expedición Libertadora al Perú. En este caso, y de manera muy breve, se incluyen también las negociaciones de paz entre el virrey Pezuela y San Martín.

\section{Lima y las primeras noticias sobre los preparativos de la Expedición Libertadora en Chile}

El 21 de abril de 1818, arribó al puerto del Callao la corbeta de guerra angloamericana Ontario con noticias de los acontecimientos de Chile. ${ }^{2}$ El virrey no tenía dudas acerca de la veracidad de estas noticias -"exageradas o no"-, por lo que dispuso una defensa general del Virreinato. Así, al comandante del Apostadero de Marina le ordenó que dispusiese el armamento de los tres buques mercantes más grandes, la $R e$ solución, la Presidenta y la Cleopatra para escoltar a los demás buques y apoyar en el bloqueo de Valparaíso recordándole:

2 Para mayor detalle sobre lo acontecido en Chile, los planes del virrey y la expedición de Mariano Osorio, véase Alvarado Luna (2014, 2015 y 2020). 
el inminente riesgo que corría el Virreynato del Perú, y en consecuencia toda la América Meridional, si no se ganaban horas en aprestar estas fuerzas marítimas para asegurar el bloqueo de Valparaíso e impedir una expedición que los enemigos debían disponer según el orden de las cosas contra las costas de Arequipa indefensas, así como lo estaba esta capital, por haber enviado las mejores y mayor parte de las tropas a la expedición desgraciada de Chile. (Pezuela, 1947, p. 250)

Así mismo, remitió órdenes al subinspector general para que los cuerpos de las milicias de Lima se pusiesen en instrucción, así como la necesidad de aumentar la guarnición en Guayaquil y de trasladar 400 soldados de las milicias de Trujillo a Lima. Previno también al intendente de Arequipa que dispusiese, con la mayor prontitud, aumentar los efectivos en el Batallón Veterano, y que se pusiese "sobre las armas un escuadrón de milicias de Tacna y el de Pardos Libres de Arica, para que estos tres cuerpos, con dos piezas de artillería ligera formasen una división volante" (Pezuela, 1947, p. 251). Estas primeras medidas respondieron a la necesidad del virrey de fortalecer las defensas de Lima, la cual, a sus ojos, era, de entre todas las ciudades, la que debía protegerse a toda costa.

Producto de las noticias desalentadoras que continuó recibiendo en los siguientes días -incluso del mismo general Osorio, encargado de la expedición de reconquista de Chile, quien llegó el 4 de mayo en la noche al palacio virreinal con la noticia de su derrota en Maipú-, el virrey Pezuela convocó en su palacio a los tribunales, a quienes les expuso que el Virreinato se hallaba "en la situación más crítica desde el principio de la revolución”, por lo que era preciso aumentar, en todo lo posible, las fuerzas militares, así como buscar los medios para sostenerlas (Pezuela, 1947, p. 261). Tras una larga conferencia, se resolvió, además de conceder privilegios exclusivos a los comerciantes españoles para introducir cualquier cargamento, nombrar una comisión "compuesta de sujetos de todas clases" autorizada para discurrir y propo- 
ner arbitrios con el objetivo de sostener las obligaciones del erario, para hacer efectivo el cobro de los predios urbanos, y para buscar "con toda prontitud" los medios para conseguir 20,000 pesos al contado y 117,000 mensuales (Pezuela, 1947, pp. 262-263). ${ }^{3}$ Lamentablemente para el virrey, el pesimismo comenzaba a surgir entre los realistas: ni las providencias ni las proclamas que el Gobierno virreinal hizo circular "ni los anuncios de los grandes refuerzos que se esperaban de España eran suficientes para calmar la inquietud" (Barros Arana, 1897, p. 217), la cual comenzó a agudizarse en los siguientes meses, especialmente entre los comerciantes limeños y jefes militares.

Pese a esto, el Gobierno virreinal continuó con sus planes defensivos. A fines de julio el virrey se volvió a reunir con el subinspector general, el subinspector de artillería e ingenieros, y el comandante de Marina en una Junta Particular de Guerra a fin de tratar las mejores medidas que se debían adoptar, así como discutir las nuevas noticias provenientes de Chile. En la reunión, entre otros puntos, se dio a conocer que San Martín había regresado de Buenos Aires y se encontraba en Mendoza "con 5,000 pesos y 1,5000 hombres" dispuesto a retornar a Chile y, junto con nuevos navíos comprados por el Gobierno chileno, a "formar una expedición contra Lima" (Pezuela, 1947, p. 297). Estas noticias, al parecer, no preocuparon mucho al virrey, pues -tal como describe- en Lima y el Callao se contaba con un total de 2,950 efectivos, divi-

3 Las personas que formaron esta junta fueron don Juan María Gálvez, intendente de Lima; don Manuel Pardo, regente del Cuzco; don Ignacio Mier, archidiácono de Lima; don Bartolomé María Salamanca, exintendente de Arequipa; don José Irigoyen, oidor de Charcas; don José Manuel Blanco Azcona, procurador general; don José Cabero, rector de la Universidad; don Pedro Abadía, factor de Filipinas; don Francisco Izcue y don José Arizmendi, comerciantes; y don Antonio Álvarez de Villar, secretario con voto. 
didos en 1,200 del Infante don Carlos, 400 Españoles del Número, 500 Pardos y Morenos, 150 Húsares de la Guardia de Honor, 200 Dragones de Lima y 500 del Cuerpo de Artillería (Pezuela, 1947, p. 299). Todas las demás provincias del Virreinato -anota- contaban con cortas guarniciones que sumaban, entre todas, unos 1,500 hombres.

Cuadro 1. Parte de las fuerzas militares en el virreinato del Perú, agosto de 1818

\begin{tabular}{|c|c|c|c|c|c|c|c|}
\hline Compañías & $\begin{array}{c}\text { Sargento } \\
1 .^{\text {ro }}\end{array}$ & $\begin{array}{c}\text { Sargento } \\
2 .{ }^{\text {do }}\end{array}$ & $\begin{array}{c}\text { Pitosy } \\
\text { tambores }\end{array}$ & $\begin{array}{l}\text { Cabos } \\
1 .{ }^{\text {ros }}\end{array}$ & $\begin{array}{l}\text { Cabos } \\
2 . .^{.5}\end{array}$ & Soldados & Total \\
\hline Granaderos & 1 & 5 & 5 & 8 & 9 & 119 & 147 \\
\hline Cazadores & 1 & 4 & 2 & 8 & 8 & 115 & 138 \\
\hline $1 .^{\text {ro }}$ de Infantería & 1 & 4 & 5 & 8 & 8 & 79 & 105 \\
\hline 2. ${ }^{\circ}$ de Infantería & 1 & 4 & 6 & 8 & 8 & 80 & 107 \\
\hline $1 .^{\mathrm{ro}}$ de Pardos & 1 & 4 & 3 & 6 & 6 & 126 & 146 \\
\hline 2. ${ }^{\circ}$ de Pardos & 1 & 4 & 2 & 6 & 6 & 103 & 122 \\
\hline $3 .^{\text {ro }}$ de Pardos & 1 & 4 & 3 & 6 & 6 & 102 & 122 \\
\hline $4 .^{\circ}$ de Pardos & 1 & 4 & 2 & 6 & 6 & 107 & 126 \\
\hline $1 .^{\text {ro }}$ de Morenos & - & 4 & 6 & 10 & 10 & 119 & 149 \\
\hline $\begin{array}{c}\text { Escuadrón Dragones } \\
\text { del Perú-Lanceros }\end{array}$ & 1 & 3 & 3 & 5 & 2 & 42 & 56 \\
\hline $\begin{array}{l}\text { Escuadrón Dragones } \\
\text { del Perú-1. }{ }^{\text {a }} \text { comp. }\end{array}$ & 1 & 4 & 2 & 5 & 4 & 40 & 65 \\
\hline $\begin{array}{l}\text { Esc. Dragones del } \\
\text { Perú-2. comp. }\end{array}$ & 1 & 4 & 2 & 3 & 4 & 38 & 52 \\
\hline
\end{tabular}

Fuente: CDIP (tomo VI, vol. 1, pp. 60-61. Anexos del 3 al 5).

Entre agosto y setiembre, el virrey se dedicó a reforzar el litoral. En el puerto de Pisco, al sur de Lima, colocó dos cañones de montaña con sus carruajes, juegos de armas y municiones; así mismo, incrementó la defensa del puerto de Quilca, en 
Arequipa, con la fragata de guerra Venganza. También, mandó aumentar la fuerza del Callao con media compañía de caballería (Pezuela, 1947, pp. 305 y 344). Estas medidas se dieron "por si el enemigo hace su desembarco en cualquiera de los puntos indicados inmediatos al Callao, ya sea por el norte o ya sea por el sur". Por ello, creyó conveniente reunir las fuerzas de los dos Batallones del Infante don Carlos $(1,102)$, el Batallón de Pardos y Morenos (607), el Escuadrón de Húsares (128), el Escuadrón de Dragones de Lima (255) y la tropa de Artillería para 20 piezas de campaña (214) fuera de Lima "sin la distracción que causa una población especialmente a los hijos de ella, para estar más prontos a caminar rápidamente o a oponérsele e impedir sus progresos y tomar por último posición para recibir una batalla" (CDIP, tomo VI, vol. 1, p. 58).

A inicios de octubre de 1818, producto de los frecuentes anuncios de la preparación de la expedición, el virrey Pezuela escribió en su Memoria que el Gobierno chileno "estaba dando disposición para armar toda la escuadra, la cual decían debía dar la vela a los 15 días" con los siguientes buques: Lautaro, con 52 cañones de varios calibres; General San Martín, con 68 cañones de entre 12 y 18; Chacabuco, con 22 cañones de 12; los bergantines Columbo, de 20 cañones de 12; Chileno, de 16 cañones; Águila, de 16 cañones; Brújula, de 14 cañones; y Maypú, de 16 cañones. Esta información, como veremos más adelante, no correspondía con la verdad: ni la fuerza de cada embarcación ni la cantidad. No obstante, no podía ser verificada "por la excesiva falta de marinería que tienen", pero que el puerto de Arica sería el primer destino de esta a fin de obtener una fuerte contribución (Pezuela, 1947, pp. 362-363). ${ }^{4}$ Debido

4 A lo largo de noviembre, el virrey continuó con los preparativos de defensa frente a la inminente llegada -según los rumores- de la expedición proveniente de Chile. Sin embargo, en Chile, la situación no era la me- 
a las diferentes noticias que recibía, a fines de diciembre, el virrey dispuso que el ejército del Alto Perú, al mando del general La Serna, con una fuerza de 5,020 hombres "y sin enemigos a su frente", debía también procurar la defensa de Arequipa y el Desaguadero y, en el caso de un ataque a Lima, estar preparado para dirigirse ahí (CDIP, tomo VI, vol. 1, pp. 212-213).

Culminaba el año de 1818 y la situación militar parecía favorecer al virrey, aunque la realidad económica era diferente. Pezuela tomó conocimiento de que el Consulado ya no era capaz de pagar la cantidad de dinero acordado en mayo. Esta situación lo llevó a entablar el libre comercio con Gran Bretaña, acción que justificó como necesaria para sufragar los enormes gastos que la guerra requería. Esta medida no implica que el virrey haya abrazado ideas liberales; más bien, muestra que, pese a su absolutismo, la complicada situación económica que vivía el Virreinato lo llevó a aceptar la aplicación del libre comercio (Alvarado Luna, 2014, p. 91). Esta decisión, como era de esperar, no fue del agrado del Consulado, pues remitió diversas quejas sobre el tema.

Hasta este momento, la escuadra realista tenía el dominio del Pacífico sur y estaba compuesta por las fragatas Esmeralda y Venganza; las corbetas Milagro, San Juan Bautista y Begoña; las fragatas inferiores Gobernadora, Comercio, Presidenta, Castilla y Bigarrera; y las corbetas Resolución, Sebastiana y 140 Veloz. El bergantín Pezuela protegía el litoral virreinal. A estas

jor. Comenzaron a surgir algunas discrepancias entre San Martín y el Senado chileno, discordias que continuarían durante los primeros meses de 1819. El Senado consideraba necesaria la expedición al Perú para así "poner en libertad al pueblo de Lima y acabar con nuestros enemigos", medida imperiosa "en las actuales circunstancias" (CDIP, tomo VIII, vol. 2, p. 16). 
naves se les sumaría pronto, desde España, la fragata María Isabel. No obstante, la escuadra chilena logró interceptar a la María Isabel y capturarla. ${ }^{5}$ Esta noticia -anotó el virrey- modificó sus planes, "pues si se hubiera unido a nuestras fuerzas marítimas del Callao, dominaríamos este Mar del Sur; las fuerzas del Virreinato y ejército obrarían activamente, el comercio saldría de su paralización y habría menos trabajos para mantener la guerra” (Pezuela, 1947, p. 384).

En Chile, por otro lado, la situación no era tan estable como se puede pensar. La inacción del Gobierno chileno hizo que San Martín le reclamara a O'Higgins la falta de disposición de apoyar la realización de la expedición al Perú. Las solicitudes de víveres, que ascendían a los 10,000 quintales de galleta y 7,000 de carne salada, "artículos abundantes en este país", así como de buques de transporte, "que debían alistarse y que en la mayor parte podían suplirse con las cinco fragatas del convoy español apresadas y otras que tiene el Estado", fueron constantemente ignoradas. Para San Martín, el envío de estos requerimientos era de suma necesidad, por lo que le increpó a O'Higgins que, de querer mantener estacionado el ejército en los Andes de Chile, por cuestiones políticas, era necesario que lo solventara, "pues de lo contrario se disuelve" (CDIP, tomo VIII, vol. 2, pp. 34-35).

En este contexto, a fines de enero de 1819, San Martín esbozó un proyecto de expedición de entre 2,500 y 3,000 hombres para tomar las costas del Perú. Según él, para atacar a Lima, “o bien para penetrar hasta el corazón del Cuzco", eran necesarios 6,100 hombres. Desgraciadamente -anotó- las rentas del Estado chileno y de las Provincias Unidas se hallaban sin los fondos suficientes para costear tal tamaño de fuerza: "ya

5 Para mayores detalles sobre la captura de la María Isabel, véase Alvarado Luna (2014, pp. 90-91); Albi de la Cuesta (2009, p. 190); Anna (2003, p. 184); y Miller (1910, pp. 68-71). 
está demasiado visto que es irrealizable, y de consiguiente no debemos mantenernos con ilusiones y sí con hechos”. Así, la expedición que proponía debía contar, según sus cálculos, "con la quinta o sexta parte del valor de los 6,100 hombres", pues el objeto de esta no era otro que "el de hacer, casi una guerra de partidarios" (CDIP, tomo VIII, vol. 2, pp. 41-42). De esta manera, el objetivo de la expedición sería hacer desembarcos en diferentes puntos de las costas del Virreinato, llamar la atención de las fuerzas realistas, fatigarlas y fomentar la insurrección.

\section{Miedos y rumores: las travesías de Cochrane en las costas del Perú (1819)}

Las correrías de Cochrane en el Pacífico crearon en el virrey Pezuela y en las demás autoridades virreinales la certeza de que el virreinato peruano correría peligro y, sobre todo, la ciudad de Lima. ${ }^{6}$ En su Memoria, el virrey señala que el capitán de la Dos Catalinas informaba del plan de Cochrane de aproximarse a Lima con unos 9,000 hombres (Pezuela, 1947, p. 392). No estaba equivocado, pues en Chile se comenzó a preparar la primera expedición al Perú con un total de 600 fusiles, 400,000 cartuchos a bala de fusil y 4,000 piedras de chispa (CDIP, tomo VIII, vol. 2, pp. 30-33). El 22 de diciembre de 1818, se enarboló su bandera en el O'Higgins y, el 16 de enero de 1819, partió a las 19:30 de Valparaíso la primera expedición comandada por Cochrane rumbo a las costas del Perú con las fragatas San Martín, de 56 cañones; O'Higgins, de 48 cañones; el convoy Lautaro, de 44 cañones, así como la corbeta Chacabuco, de 20. La segunda división estuvo compuesta por el Araucano, de 16,

6 Al poco tiempo de llegar a Chile, a Cochrane se le confirió el título de vicealmirante de Chile, almirante y comandante en jefe de las Fuerzas Navales de la República. 
y el Galvarino, de 18, al mando de Blanco de Encalada (Cochrane, 1905 , p. 13). ${ }^{7}$

Hasta el 21 de febrero, la escuadra chilena estuvo a una distancia suficiente para no ser vista desde el puerto. El ataque al puerto y a las embarcaciones que se encontraban ahí estaba planeado para el día 23, "último día de carnaval y el más probable que muchos oficiales y soldados de la guarnición se hallasen, según costumbre, con licencia en Lima" (Alvarado Luna, 2014, p. 95). No obstante, el mal clima produjo que la escuadra se separase y el ataque fuese suspendido por unos días.

El virrey manifestó que, el 26 de febrero, a tres leguas del morro Solar, se avistaron cinco fragatas y un bergantín sospechosos, por lo que despachó 50 cazadores y 50 dragones para reforzar dicho punto. Dos días después, el virrey se dirigió a pasar revista de las fuerzas útiles y buques de guerra en el puerto del Callao. La mañana estaba oscura -describe- y apenas se veían las maniobras desde la corbeta Sebastiana, en la que estaba embarcado, por lo que decidió trasladarse al bergantín Maypú. Anota que la operación se inició a las siete y entrada la mańana el virrey procedió a pasar revista a los buques de guerra (Pezuela, 1947, p. 410). A las once, Pezuela divisó una fragata y le solicitó al comandante del Maypú que se acercase a ella; sin embargo, este se opuso argumentando que "estaba prohibido reconocer ningún buque teniendo la primera autoridad del reino a su bordo", con lo cual el virrey desistió de su pedido (García Camba, 1846, p. 303). Una hora y media después, el virrey retornó a Lima. A las tres de la tarde, apenas había entrado el virrey en su palacio, se oyeron bombardeos: el ataque planeado por Cocharen al Ca-

7 En sus Memorias, Guillermo Miller sugiere una cantidad de cañones diferente: O'Higgins, 50; San Martín, 56; Lautaro, 48; y Chacabuco, 20. Véase Miller (1910, p. 183). 
llao había dado inicio. En el parte de don Antonio Vacaro, comandante general del Apostadero del Callao, dirigido al virrey, se puede leer lo siguiente:

nosotros hemos tenido 15 hombres muertos y 2 heridos, algunas averías en los buques, y según el parte que me acaban de dar no está en línea la lancha número 4, que era la cola de la formación de esta marina, y que por causa del viento y la marejada envueltos en espesa niebla fueron todos sotaventeándose, cuya lancha tal vez cortada por los enemigos habrá arribado a la costa de sotavento [...]. Todos, señor excelentísimo, oficialidad, tropa, marineros, maestranza, compañía de cargadores y naturales indios han estado llenos de aquel ardor que inspira la lealtad en contraste con la traición. (CDIP, tomo VII, vol. 2, pp. 24-26)

Por su parte, don Fernando Javier de Reyna, teniente gobernador del Callao, sobre el mismo tema, le comunicó virrey:

Se han encontrado dentro de esta plaza hasta diez balas de a veinte y cuatro y de a diez y ocho, habiendo pagado muchas más en los merlones del baluarte de la Reyna, y tengo la satisfacción de decir a VE que el espíritu, y presencia de ánimo con que trabajó la artillería, y el acierto de sus tiros han sido dignos de todo aplauso; como asimismo el batallón de Burgos que está de guarnición, que con sus jefes y oficialidad se pusieron sobre las armas desde el primer tiro de cañón apeteciendo y manifestando deseos de sacrificarse en defensa del rey, y lo propio el pequeño número de zapadores, y dragones de Carabayllo, dignos todos del mejor aprecio, manteniéndose toda la noche con vigilancia y puntualidad en el cumplimiento de las órdenes que tenían, sin haber resultado desgracia alguna en la plaza. (CDIP, tomo VII, vol. 2, p. 27)

Finalmente, el 1. ${ }^{\text {ro }}$ de marzo, quedó establecido el bloqueo del Callao, medida que contaba con el apoyo del Gobierno chileno y de O'Higgins, los cuales indicaron a Cochrane, entre otros puntos, bloquear todos los puertos desde Guayaquil 
hasta Atacama; prohibir a todos los buques "de hacer tráfico o de tener ninguna comunicación con los puertos" dentro de los límites del bloqueo; y permitir la salida de navíos neutrales de cualquier puerto incluido en el bloqueo tras ocho días de haberse iniciado (CDIP, tomo VIII, vol. 3, pp. 115-116). A los pocos días, Cochrane "atendiendo a la balanza actual de prisioneros de guerra que Chile tiene en su poder y a favor de un número excesivo de españoles", le escribió y envió al virrey un parlamentario para solicitarle el canje de prisioneros y "el buen trato de los del bergantín Maypü" (CDIP, tomo VII, Vol. 2, pp. 30-31); Pezuela accedió, pese a considerar que la conducta de Cochrane no merecía tales servicios (Pezuela, 1947, p. 413).

Los rumores sobre el arribo de la expedición preparada en Chile no dejaron de llegar ni siquiera durante el bloque del Callao; incluso, se aseguraba que esta se realizaría a fines de marzo o principios de abril y que su destino serían las costas de Arequipa. Debido a ello, el virrey encomendó al coronel Lóriga que diese aviso al comandante general del Cuerpo de Reserva "a fin de que estuviese prevenido y se dirigiese al general del Ejército del Alto Perú, con igual diligencia, el pliego que le acompañaba por igual aviso para que estuviesen prevenidas algunas tropas con qué reforzar al Cuerpo de Reserva en caso necesario" (Pezuela, 1947, p. 414). Los ataques y el bloqueo de la escuadra comandada por Cochrane continuaron a lo largo de marzo, tiempo que aprovechó para remitir a Chile información sobre la situación del Virreinato. Así, por ejemplo, se dio a conocer que Lima contaba con una fuerza total de 6,685 hombres de tropa y 271 oficiales, como se presenta en el cuadro 2 . 
Cuadro 2. Fuerzas militares en Lima, 1819

\begin{tabular}{|l|r|c|}
\hline Nombre de la fuerza & $\begin{array}{c}\text { Número de } \\
\text { tropas }\end{array}$ & $\begin{array}{c}\text { Número de } \\
\text { oficiales }\end{array}$ \\
\hline 1. $^{\text {er }}$ Batallón Don Carlos & 843 & 37 \\
\hline $\mathbf{2 .}^{\text {}}$ Batallón Don Carlos & 507 & 14 \\
\hline 3. $^{\text {er }}$ Batallón Don Carlos & 712 & 22 \\
\hline Burgos con Negros & 576 & 17 \\
\hline Arequipa con Negros & 444 & 16 \\
\hline Cantabrina & 267 & 15 \\
\hline Número 4 de Milicias & 482 & 20 \\
\hline Concordia & 1,500 & 56 \\
\hline Artillería & 500 & 28 \\
\hline Caballería & 350 & 20 \\
\hline Dragones Total & 354 & 24 \\
\hline Guardia del Virrey & 150 & 12 \\
\hline & 6,685 & 271 \\
\hline
\end{tabular}

Fuente: CDIP (tomo VIII, vol. 2, pp. 23-34).

A la 1 de la mañana del 23 de marzo, Cochrane atacó la línea marítima e intentó quemar, aunque en vano, los buques que se encontraban en el puerto. Ante esta acción, Pezuela consideró que el almirante "no perdona astucia alguna, sea o no admitida en la guerra, que no emplee para conseguir sus san-

146 guinarios e inicuos proyectos, cuando por otra parte anuncia en sus proclamas que no es un intento hacer la menor estorsión a los vecinos pacíficos" (Pezuela, 1947, p. 417). Cuatro días después, finalmente, la escuadra chilena abandonó las costas del Callao tras el ataque de algunas lanchas cañoneras un par de días atrás. Aprovechando esta situación, el virrey dispuso a los jefes de la costa sur y norte que tuviesen el mayor cuidado, especialmente en Chancay y Huaura, mientras que, desde Trujillo, Francisco Gil, comandante general de 
dicha plaza, remitió armas y municiones para la defensa de la costa norte. ${ }^{8}$

A inicios de abril, tras dejar al almirante Blanco en Huacho con el San Martín y el Pueyrredón, Cochrane navegó hacia Supe con el O'Higgins y el Galvarino "habiendo sabido de antemano que una suma de dinero para pagar a las tropas españolas estaba en camino de Lima para Huanchaco"; entonces, se apoderó del dinero, que ascendía a 70,000 pesos, en Pativilca (Cochrane, 1905, p. 22). A fines del mismo mes, el virrey Pezuela recibió correspondencia en la que se le confirmó el envío de los dos navíos y una fragata a las costas del Virreinato, la salida del batallón de Numancia de Quito hacia Lima con 1,132 plazas y que la expedición contra el Río de la Plata "se estaba aprontando para salir escoltada por 4 navíos, 6 fragatas y varios buques" (Pezuela, 1947, p. 445). Estas noticias fueron bien recibidas por él, pues le permitían continuar con sus planes de defensa para Lima y la costa virreinal. A lo largo de mayo, el virrey volvió a recibir noticias sobre los movimientos de San Martín, por lo que, en los siguientes días, dispuso el refuerzo de la costa y, especialmente, de Lima, tanto mediante tropas como mediante municiones y alimentos (Pezuela, 1947, pp. $452-458$ y 472-473).

Cuando Cochrane arribó al puerto de Valparaíso a mediados de junio, se encontró con el almirante Blanco, quien se había visto en la necesidad de levantar el bloqueo de las costas peruanas por falta de provisiones. Esta decisión fue del desagrado del Gobierno chileno, el cual Cochrane consideró "era quien, con mayor razón, debía censurar su propia negligencia o falta de previsión al no preverles de lo necesario" (Cochrane, 1905, p. 25). Pese a esto, los principales

8 AGN.SU.GO-BI-BI3.120, 288. La retirada de la escuadra chilena el 27 de marzo le confirmó al virrey lo imperioso de establecer el libre comercio, medida que ya había pensado adoptar meses atrás. 
objetivos de la expedición al Perú ya se habían concretado: el reconocimiento de las costas y la constatación de "las inclinaciones de los peruanos respecto a si deseaban emanciparse". Esto era fundamental para el Gobierno de Chile, ya que se sentía en la obligación de "mantener una perpetua vigilancia a fin de conservar sus libertades recientemente adquiridas" (Cochrane, 1905, pp. 25-26). ${ }^{9}$ El 12 de agosto, la escuadra compuesta por el O'Higgins, San Martín, Lautaro, Independencia y Pueyrredón se hizo a la vela con una tripulación compuesta, en su mayor parte, "de paisanos del país, a quienes era difícil convertir en buenos marinos, aunque se batían con bizarría cuando estaban bien mandados" (Cochrane, 1905, p. 29). El 23 de setiembre fondearon en el Callao la fragata Esmeralda, la corbeta Presidenta, el bergantín Pezuela y otros tres transportes con 700 hombres de tropa a bordo, 34 cańones de diversos calibres y una considerable porción de municiones y pertrechos de guerra, todos procedentes de Talcahuano (CDIP, tomo VII, vol. 2, p. 16); a fines de mes -anotó el virrey-, se presentaron los buques enemigos en las inmediaciones de la isla San Lorenzo, a lo que este respondió reforzando con 200 hombres del Infante Don Carlos y otros tantos del Concordia la plaza del Callao (Pezuela, 1947, pp. 532-533).

Octubre inició con nuevos ataques de la escuadra de Cochrane sobre el Callao. Mediante la preparación de algunas balsas incendiarias, pruebas de disparos, y la aproximación a las balsas y a un bergantín que se encontraban en el puerto, se

9 En los siguientes meses, en el virreinato peruano, se supo que, en Valparaíso, se comenzaba a preparar una nueva expedición contra el Perú, la cual culminó sus preparativos a inicios de setiembre (Barros Arana, 1897, p. 453). Para poder financiarla, el Estado chileno tuvo que realizar imposiciones forzosas a las fortunas particulares. Los caballos y mulas -sostiene Bulnes- se obtuvieron en las haciendas "por medio de comisiones compuestas del teniente gobernador del partido" (1887-1888, p. 202). 
buscó generar pánico entre la población del puerto y de Lima hasta el 8 del mismo mes. Ese día, Cochrane elevó anclas, al considerar inútil su permanencia en las inmediaciones del puerto, puesto que las instrucciones le ordenaban no acercarse a los buques "a tiro de las baterías enemigas, ni acometer de modo alguno a su escuadra, excepto con los cohetes y brulotes". Sin embargo, sus principales razones para culminar los ataques estuvieron relacionadas con la recién llegada fragata Prueba, la cual se guarecía en Guayaquil (Cochrane, 1905, pp. 33-34).

La repentina retirada de Cochrane hizo que el mismo virrey se dirigiese al Callao a dar personalmente las gracias a todos los jefes, oficiales, y tropa de tierra y mar

que tan valiente y decididamente se portaron en los siete ataques nocturnos que dio el aventurero Cochrane, empleando con toda obstinación sus buques menores, lanchas, cohetes, un brulote, balsas y cuanto supo para destruir los buques y población, tan inútilmente, por la bien sostenida defensa que se hizo, de que le quedaría memoria a Cochrane para su vergüenza y la de todos los insurgentes. (Pezuela, 1947, p. 544)

Temeroso de un nuevo ataque, a fines de noviembre, el virrey Pezuela convocó una Junta de Guerra para tratar los acontecimientos que estaban acaeciendo en Santa Fe y Popayán, los recelos en Quito y la solicitud del cabildo de dicha ciudad para que Juan Ramírez vuelva al mando, debido a que no existía confianza en el mariscal de campo Aimerych y la manera de defender la costa del Virreinato (Pezuela, 1947, pp. 571-572). De este modo, el año culminaba para el virrey con mayores problemas y temores sobre el devenir de los territorios que al inicio. A sus ojos, la pérdida de Chile era un problema lejano en comparación con la crítica situación que se avecinaba en los siguientes meses. 


\section{El arribo de la Expedición Libertadora al Perú}

El 1. ${ }^{\text {ro }}$ de enero de 1820, en Cabezas de San Juan, España, el general Rafael de Riego "levantó la bandera de la revuelta" y reinstauró el sistema constitucional de 1812. Con el arribo de refuerzos, dos meses más tarde, el rey Fernando VII se vio obligado a aceptar el sistema que tanto aborrecía y que había tratado de suprimir desde su regreso en 1814 (Costeloe, 2010, p. 110). Esta situación truncó los planes del rey de una reconquista puramente militar de América, pues perdió sus facultades como monarca absoluto, se vio obligado a jurar la Constitución Liberal el 9 de marzo y tuvo que aceptar la convocatoria a nuevas Cortes el 22 del mismo mes. Estas nuevas Cortes, con mayoría liberal, no colocaron a América como uno de los primeros puntos de la agenda del nuevo Gobierno -lo que no implica que la situación americana fuera un tema sin importancia para estas-; sin embargo, dicha situación se conoció en el virreinato peruano, de manera oficial, recién en setiembre, lo que explicaría por qué el virrey concibió sus planes de defensa en 1820 tomando como base los refuerzos prometidos por España (Costeloe, 2010, p. 117). Así, tal como hemos visto, pese a los rumores, en ocasiones el virrey continuaba dudando de la veracidad del zarpe de la Expedición Libertadora, pues mantenía la esperanza en la llegada de refuerzos peninsulares a Buenos Aires, y confiaba en que el ejército de los Andes sufría de una falta de medios económicos, así como de posibles divisiones entre sus altos mandos (De la Puente Candamo, 1971, p. 245).

Para el virrey Pezuela, 1820 inició con los esfuerzos del virreinato peruano de mantener el flujo comercial y el suministro de las tropas realistas aún presentes en Chile, por lo que ordenó que se embarque trigo y zurrones con harina, así como garbanzos, frijoles, lentejas, charque, arroz y vestimenta para la tropa, todos a bordo de la fragata 
inglesa Luisa. Su capitán, John Ward, debía comprar estos víveres al precio más cómodo y cargar los frutos que consiga para entregarlos luego en Valdivia y Chiloé. Esta fue la única forma que encontró el virrey de socorrer a las fuerzas realistas en la región, pues consideraba que "sería aventurado el envío de ellos en buques nacionales, en atención a hallarse estos mares llenos de corsarios" además estos víveres y vestimentas "costarían en esta plaza acaso un duplo de los precios asignados, con lo que resulta beneficiada la Real Hacienda y socorridos ambos puntos" (Pezuela, 1947, pp. 629-631).

Pese a la situación de incertidumbre, el comercio interno del virreinato peruano continuó durante los primeros días del ańo gracias al levantamiento del bloqueo del Callao. De esta manera, el 20 de enero, entraron en el Callao 2,140 sacos de trigo y algunos de arroz, harina y garbanzos procedentes de Huanchaco y, a los pocos días, de Valparaíso, 6,115 fanegas de trigo, 47 zurrones de sebo, 25 líos de charque y 20 marquetas de cera (Pezuela, 1947, pp. 633-634). Para finales de mes, con el arribo del bergantín inglés Dos Catalinas, se conoció en Lima que San Martín había ingresado en Santiago proveniente de Mendoza con una tropa de 3,500 hombres; que, en Santiago, Valparaíso y otros puntos había unos 5,000 hombres; y que se "hablaba mucho de la expedición contra el Perú por la costa de Arequipa según unos y á Guayaquil según otros, aunque también decían que sería en derechura á Lima” (Pezuela, 1947, p. 638).

En las siguientes semanas, y a lo largo de febrero y marzo, continuó el arribo de cargamentos de trigo, sebo, bacalao, arroz y frijoles a Lima. Por otra parte, el cabildo de la ciudad presentó una solicitud para que Pezuela, pese a las dificultades administrativas, permaneciese a la cabeza del Virreinato, pues consideraba su "genio ecuánime y próvido" lo necesario 
para paralizar "esfuerzos bárbaros y sanguinarios" de los independentistas (CDIP, tomo VIII, vol. 3, p. 309). Esta solicitud respondió a las constantes quejas que, en estos meses, comenzó a hacer el virrey sobre los estragos de la guerra sobre su salud. Sin embargo, creemos que también se debió a un intento por parte del cabildo, en complicidad con el Consulado, para que el virrey diese marcha atrás su intensión de implementar el libre comercio.

En este contexto -y quizá debido a solicitud del cabildo limeño-, en una Junta Militar, se determinó que los batallones del Centro y Gerona se trasladasen a Lima desde Oruro (por la vía de Puno, Cuzco y Huamanga), a fin de reforzar la capital, pues, para el virrey, de la seguridad de la Lima "dependía todo el Virreynato y estando amenazada [...] de una expedición que para imbadirla estaba formando en Chile el caudillo San Martín, libre de las atenciones que le había ocupado, [...] era preciso tomar esta medida á que daba lugar el Ejército del Perú”. Para no dejar desprotegidos esos puntos, el virrey le indicó al general del Ejército que sustituyese con algunas fuerzas del lugar a esos batallones "apenas ya necesario en Oruro, por haber tranquilizado las provincias de La Paz, Cochabamba y Chuquisaca, acabando con los caudillos que bajaban por ellas" (Pezuela, 1947, pp. 649-650).

De esta manera, la defensa de Lima se convirtió -ya de forma oficial- en un asunto central para el virrey, así como la necesidad de mantener provisionada la ciudad y al día el pago de las tropas. A fin de examinar las recomendaciones de la Junta de Arbitrios, Pezuela convocó a una Junta a fines de febrero; como resultado, se tomaron más de 60,000 pesos de la Casa de la Moneda y otros que tenía depositado ahí el Tribunal de Minería, pertenecientes a la Junta de Reemplazos de Cádiz. La finalidad era ayudar al pago de la tropa y formar una Junta de Comercio que se propusiera conseguir 100,000 pesos para 
auxiliar al ejército del Alto Perú y al cuerpo de reserva "que estaban a pique de disolverse por no haber con qué pagarlos, especialmente el de Reserva”. Además, se solicitó un préstamo al Erario de 115,000 pesos mensuales por cuatro meses (Pezuela, 1947, pp. 657-658; véase Alvarado Luna, 2014, pp. 109-115).

Nuevas noticias procedentes de España comenzaron a preocupar al virrey, pues el 5 de marzo recibió correspondencia que no abordaba el tema de la expedición militar sobre el Río de la Plata "ni de auxilios a Lima" que tanto se le habían prometido y anunciado para inicios de 1820. Sin embargo, en cartas particulares, se le informaba sobre "una fuerte epidemia de peste" en Cádiz que obligó a la expedición a Buenos Aires a retirarse al interior de Andalucía (Pezuela, 1947, p. 671). A quincena de mes, siguiendo el plan de defensa de Lima, arribó al Callao la fragata Presidenta, proveniente de Guayaquil, con un cargamento de 2,119 sacos de cacao, 1,000 suelas, 130 capachos de alquitrán, 172 tablones de cedro, 200 mangles, 50 alfajías, 150 ligazones, 19 baúles de efectos y 120 tercios retobados de efectos. En la fragata Mexicana, procedente de Huanchaco, arribaron al Callao 2,854 sacos de trigo, 978 de arroz y 124 de harina. Con el bergantín angloamericano Cantón, procedente de Pisco, fondearon en el Callao 1,535 botigas de aguardiente, 15 botijas de pisco, 12 botijas de aceitunas, 20 tercios de palma y 763 botijas de vino. Con el bergantín español Especulador, procedente de Guayaquil, llegaron 815 cargas de cacao, 1,500 suelas, 3 cajones de sombreros, 2 cajones de pita, 2 cajones de café, 20 líos de paja para sombrero, 50 líos de alfajías, 70 medias y 4 palos de balsa. Con el bergantín Regencia, procedente también de Guayaquil, arribaron al puerto " 853 sacos de cacao, 2,860 suelas, 52 zurrones, 14 baúles 'del país', 28 botijas de tamarindo, 17 tercios de balaustres y 50 hualtacos". Finalmente, con el bergantín angloamericano Elena María, procedente de Huanchaco, 
fondearon 1,583 costales de trigo, 577 costales de arroz, 8 tercios de retenía y 60 petacas de jabón (Pezuela, 1947, pp. 675-676 y 679-680).

En esos días, partieron rumbo al Callao las dos compañías del Regimiento de la Concordia "acordadas en el plan de defensa”, las dos compañías del Numancia y el Batallón de Arequipa, este último acantonado en Bellavista. A inicios de abril, y a fin de subir la moral de los oficiales realistas, el virrey decidió premiar con el grado militar inmediatamente superior a los jefes que habían defendido el Callao de los sucesivos ataques de Cochrane y su escuadra. De los dieciséis oficiales, ascendieron al grado de mariscal de campo José La Mar, Manuel Llano y Antonio Vacaro; al grado de brigadieres, Francisco Reyna, Juan Antonio Monet y Tomás Blanco Cabrera; a coroneles, Rafael Ceballos, Ruperto Delgado y José Rodil (Pezuela, 1947, p. 692). Para fines de mes, se dispuso el desacuartelamiento de 380 miembros del batallón de Arequipa, "quedando poco más del quarto de cada una de sus compañías, porque ni el Consulado ni la Junta de Arbitrios ni corporación alguna" de las que fueron reunidas en el palacio virreinal presentaron arbitrios con que cubrir 196,000 pesos que faltaban para pagar las obligaciones militares del entrante mes de mayo. Esta solicitud -anota el virrey- lo llevó a un apuro tan grande como "nunca me vi en los cuatro ańos de este penoso mando" (Pezuela, 1947, pp. 703-704).

154 Los problemas económicos se agravaron en mayo, al punto que el virrey anotó que el Consulado no pudo cumplir con el pago de los 40,000 pesos ofrecidos al Ejército. Pezuela plasmó su angustia frente a las constantes necesidades económicas en el Virreinato: "No es explicable las angustias que paso por falta de Plata para mantener la Guerra, ni el Rey tiene con qué recompensar a un virrey que se ve ya por espacio de 4 años como yo, teniendo que sufrir hombres 
sin crianza, mezquinos, y acaso poco leales, por conservarle estos Dominios" (Pezuela, 1947, p. 706). Una nueva Junta General de Tribunales se celebró a fines de mes. En esta, se continuó discutiendo el estado en el que se encontraba el virreinato peruano y se enfatizó que eran precisos 160,000 pesos para el préstamo de la tropa y otros 600,000 para socorrer al Ejército, Cuerpo de Reserva, Chiloé, Arauco, Santa Fe, la división del comandante Calaza en Popayán y al comandante general de Panamá. Por otro lado, se acordó el cobro de $5 \%$ de los precios rústicos en Lima, en Trujillo y Huancavelica; el establecimiento de una contribución en Lima; la ampliación de las facultades del virrey para conceder permisos mercantiles; y, finalmente, el pago de 2,000 pesos que el Tribunal del Consulado había ofrecido (Pezuela, 1947, pp. 713-714).

El 30 de mayo, gracias al arribo del bergantín angloamericano Dick, se conoció, mediante impresos provenientes de Buenos Aires, el levantamiento de las tropas del ejército en Espańa, noticias que fueron confirmadas el 9 de junio por las novedades llegadas con la fragata Ana de Ríos, procedente de Río de Janeiro. El virrey tuvo conocimiento, además, de que el levantamiento de las tropas en Cádiz fue puramente militar y que, según decían "no hubo un pueblo español que faltase a la fidelidad al Rey", por lo que consideraba que eran "inventadas por los perturbadores del orden público, de poner en movimiento todas las milicias de la Península falsificando la firma del Rey y Ministros para conseguirlo, para dar empleos, y quitar otros, y finalmente para ocasionar con Reales Órdenes fingidas el descontente general de la Nación con el Rey y entorpecer por este medio la salida de Expedición contra el Río de la Plata” (Pezuela, 1947, pp. 718-719 y 723).

A lo largo de junio, continuaron arribando a la capital los refuerzos provenientes de los diferentes puntos del Virreina- 
to, especialmente de la costa, como Huaura, Ica y Cañete, o Tarma, a los cuales se solicitaron caballos y tropas de infantería; también llegaron diversos transportes al Callao con sal, azúcar, menestras, algodón y otros productos. ${ }^{10} \mathrm{~A}$ inicios de julio, se le confirmó al virrey, vía Panamá, la jura de la Constitución gaditana en España, información que vino acompañada con un decreto del rey fechado el 7 de marzo, en el que se mandaba restablecer la Constitución de las Cortes Extraordinarias (Pezuela, 1947, p. 728).

El virrey se mostró escéptico frente a estas noticias, al considerarlas un invento de los independentistas para causar zozobra entre la población virreinal y desestabilizar al Gobierno, lo cual comenzaba a producirse. A esto se sumó que, mediante el bergantín angloamericano Warrior, procedente de Río de Janeiro, se supo de la preparación en Valparaíso de una expedición de 6,000 hombres comandada por San Martín y convoyada por Cochrane con los buques María Isabel, Independencia y Araucano, listos para zarpar, mientras que los demás se encontraban en rápidas reparaciones. Así mismo, se conoció una proclama de San Martín a su ejército en la que se anunciaba la preparación de la expedición contra el Virreinato "en unos términos que parece no queda duda de que se verificará pronto" (Pezuela, 1947, pp. 730-732).

Los temores del virrey sobre la expedición de los independentistas se hicieron, finalmente, realidad, por lo que fue necesario apresurar la defensa de la capital. Para esto, y debido a la escasez de dinero y el poco auxilio que podían prestar los habitantes en su defensa, se descuartelaron los batallones de Españoles, Arequipa, Dragones de Lima y Carabayllo, así como la mitad de la guarnición de Cañete y Pisco. A la par, resolvió que volviesen a tomar las armas "los

10 AGN.SU.GO_CO2_214,4497; AGN.SU.GO_CO2_214,4543. 
que las dexaron y pudiesen encontrarse, respecto a que toda la Guarnición de Lima consiste en el día de 2,600 hombres por la imposibilidad de mantener más, sin buscar medios extrahordinarios no hallados hasta el día para conseguirlo" (Pezuela, 1947, p. 732). Por esos días, diversos pasquines y avisos que manifestaban la voluntad de jurar la Constitución gaditana -y aseguraban, incluso, que el virrey tenía la orden para ello- se encontraron en varias esquinas de la ciudad; los rumores se hicieron cada vez más frecuentes a medida que en Lima continuaban arribando las noticias provenientes de España.

En los primeros días de agosto, el virrey ordenó que se recogiesen caballos, ya sea prestados, comprados o mediante donativos de Huaura, Cañete e Ica para la caballería del ejército de Lima, pues hacían falta unos 400. Así mismo, se ordenó al subinspector general que se dirijan a Lima 50 hombres escogidos a fin de que esta pudiera tener 100 plazas. Similares solicitudes se realizaron para la compañía de Dragones de Lima y el regimiento de Milicias de Huaura (Pezuela, 1947, p. 741). Pese a los esfuerzos, no todos lograron cumplir las órdenes del virrey. Uno de estos fue el comandante de Huaura, Augustín Otermín, quien, ante la solicitud de enviar 300 hombres de su batallón, solo envió 100; argumentó que, de cumplir con todo el pedido "quedaría una fuerza insuficiente para incomodar al enemigo e imponer y sujetar a estos Pueblos y los de la sierra que [...] es a donde se encuentra la gente viciada y afecta a la insurrección" (CDIP, tomo VI, vol. 3, p. 15).

En Chile, el embarque del ejército expedicionario -con aproximadamente 4,500 soldados repartidos en dos divisiones: Andes y Chile- se inició el 19 de agosto (Bulnes, 1887-1888, p. 207). ${ }^{11}$ Al día siguiente, se embarcaron los últimos res-

11 Según la información que se encuentra en la CDIP y que se expone 
tos del ejército, la intendencia y la Comisaría de Guerra, el Estado Mayor y el Cuartel General; ese mismo día, por la tarde, zarpó del puerto de Valparaíso la expedición bajo la protección de la bandera de Chile "en medio de las salvas de la artillería de mar y tierra y de las a aclamaciones del pueblo" (Espejo, 1978, p. 18). ${ }^{12}$

en los cuadros 3 y 4, en julio de 1820, el Ejército Libertador del Perú contaba con 3,393 hombres de infantería, 717 de caballería y 532 de artillería, lo que sumaba 4,642 efectivos. La información desagregada de la cantidad de miembros dentro de las Planas Mayores, oficiales y tropa se puede consultar en el anexo entre las páginas 94 y 95 de CDIP tomo VI, vol. 2 .

12 Cochrane se encontraba al mando de la O'Higgins, acompañado por la Lautaro y el Galvarino, mientras las tropas de desembarco lo seguían en doce transportes formados en columna. En la segunda línea, se encontraban seis transportes que conducían el material de guerra, los cuales estaban flanqueados por la Moctezuma y el Arauco. Por su parte, la retaguardia era formada por once lanchas cañoneras. Cerraban la expedición la Independencia y el San Martín, el cual conducía al Estado Mayor, compuesto por Rudecindo Alvarado, Juan Antonio Álvarez Arenales, Juan Gregorio de Las Heras, entre muchos otros (véase Albi de la Cuesta, 2009, p. 256 y Bulnes, 1887-1888, pp. 207-213). Según sostiene Espejo: "La fragata Emprendedora llevaba 1,280 CAJONEs de cartuchos de fusil a bala y 1,500 bultos de parque, incluso cajas de herramientas y diversos útiles de maestranza. La fragata Mackenna conducía 960 cajones de armamento y correaje de repuesto para infantería y caballería y 180 quintales de hierro de toda clase. El bergantín Nancy llevaba 80 caballos para las primeras operaciones de desembarque, fuera de los que iban en el navío San Martín y otros transportes de cada división. La goleta Golondrina llevaba 100 cajones de cartuchos de fusil a bala, 190 fardos de vestuarios, 460 sacos de galleta y 670 líos de chaque de reserva" (1978, p. 18). 


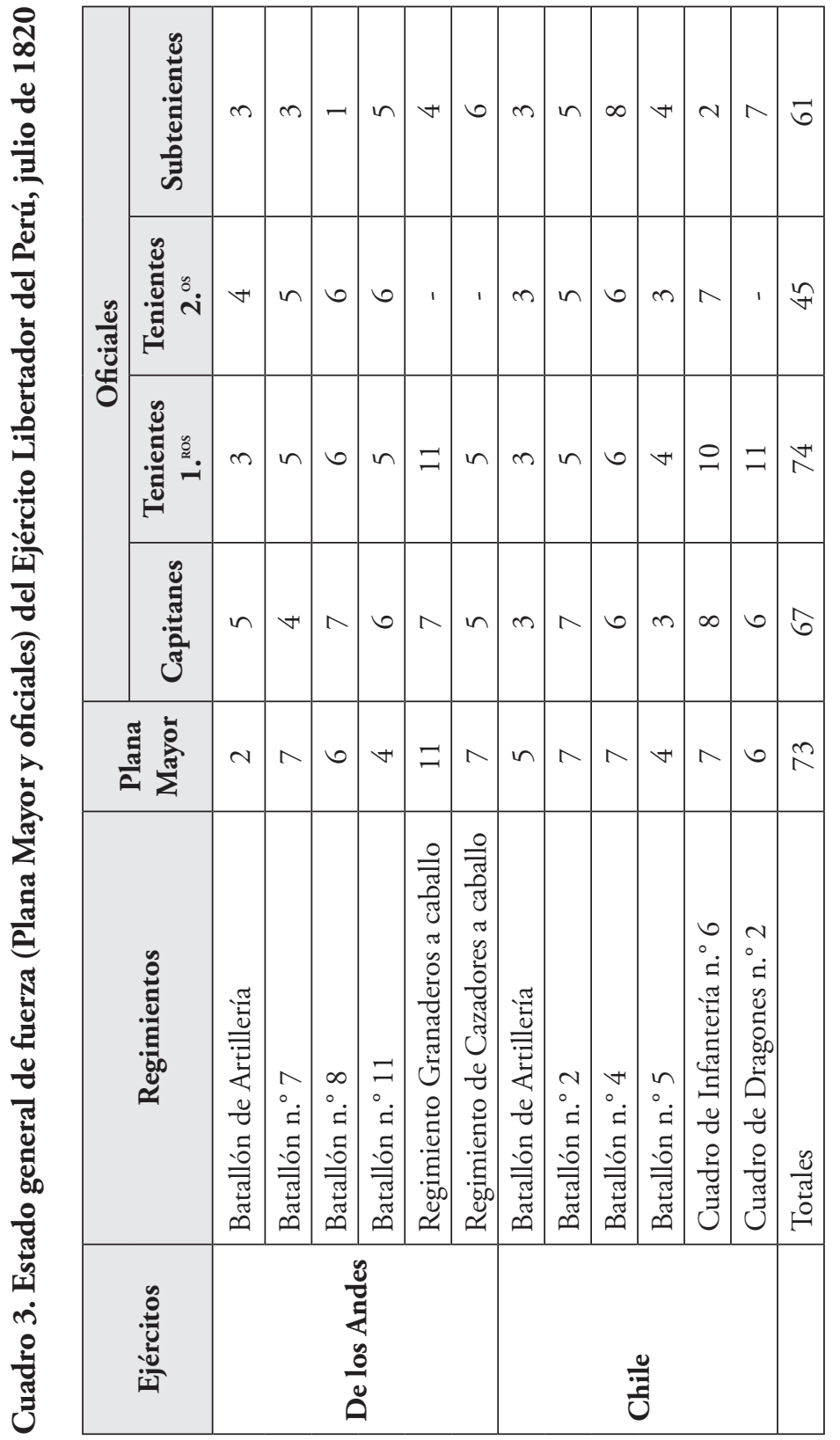

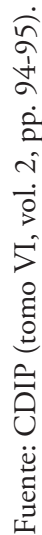




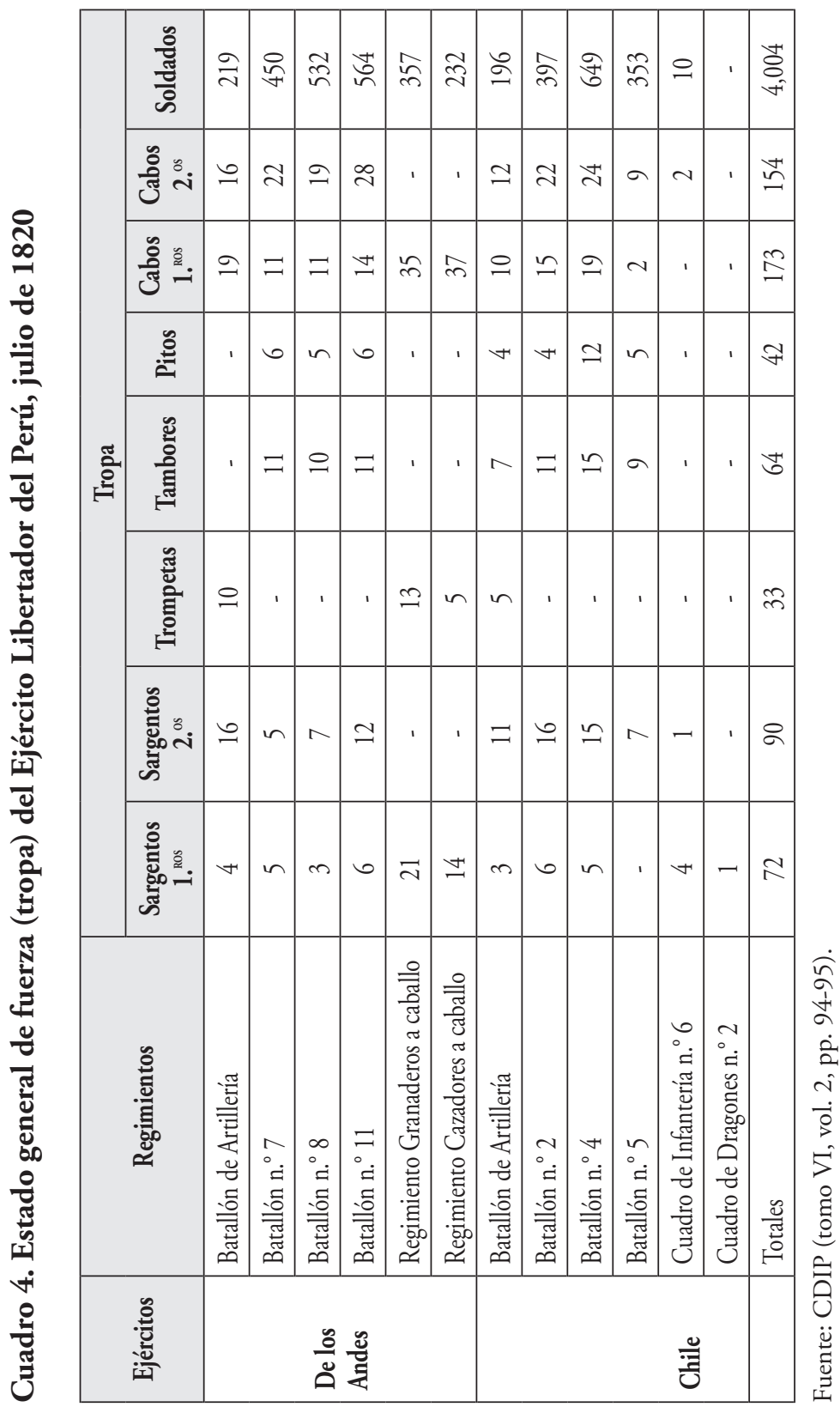


"Ya la ciudad de Lima estaba persuadida de que la expedición que en Valparaíso aprestaba el enemigo á las órdenes de San Martín y Cochrane debía salir pronto de aquel Puerto y que su obgeto era atacar por algún punto de las Costas a este Virreynato ó directamente á Lima”, escribió el virrey el mismo 20 de agosto. Por este motivo -consideraba el virrey-, era necesario dar confianza a la población "presentándole las tropas con que me hallaba y las prácticas destinadas a la defensa interior de la ciudad". Para esto, revisó el ejército que se hallaba en la ciudad: 4,190 hombres repartidos entre los batallones del Infante, Cantabria, Vitoria, Numancia; dos escuadrones de Húsares, uno de la Unión, otro del Rey; y 16 piezas de artillería. A estos se les sumaban las fuerzas de los batallones de Arequipa, el escuadrón Dragones, el de Carabayllo y 8 piezas de artillería, lo que sumaba 5,140 efectivos (1947, pp. 748-750).

El 26 de agosto, tras pasar por Coquimbo y reunirse con el bergantín Arauco, la escuadra chilena volvió a desplegar velas. En este momento, el general San Martín le hizo conocer a Cochrane su intención de dirigirse con el cuerpo principal del ejército en dirección a Trujillo, pues estaba seguro de que las buenas relaciones entre el intendente de dicha ciudad, José Bernardo de Torre Tagle, y Bernardo O’Higgins serían de suma ayuda; sin embargo, "hallando que todo razonamiento era infructuoso" con Cochrane, optaron por dirigirse rumbo a Pisco (Cochrane, 1905, pp. 79-80).

Recién el 4 de setiembre, se conocieron en Lima, de manera oficial, las noticias de Madrid referentes a la restauración del liberalismo, la necesidad de jurar la Constitución y las instituciones referentes a las negociaciones de paz con los "insurgentes". Al virrey, la situación le representó un nuevo problema: si bien sabía que existía una posibilidad, aunque remota, de disuadir a los independentistas, o a aquellos tentados a unírseles, las libertades propuestas por la Constitución po- 
dían ser perjudiciales en la complicada situación que vivía el virreinato peruano (Peralta Ruiz, 2010, p. 287). A esto hay que sumarle las críticas que comenzó a recibir por parte de sus propios generales sobre la forma en cómo estaba llevando a cabo la guerra y las pocas medidas adoptadas para frenar las incursiones de Cochrane.

El 7 de setiembre, a las 18:00, arribó la escuadra chilena a Paracas. Al día siguiente, a las 16:00, se procedió con el desembarco. Los primeros fueron algunos miembros del batallón $\mathrm{n} .{ }^{\circ} 11$ a fin de explorar el campo por si había alguna emboscada o fuerza enemiga que se opusiera al desembarco (Espejo, 1978, p. 25). Sin embargo, al no encontrar mayor resistencia, continuaron con el desembarco los batallones $\mathrm{n} .^{\circ}$ $7 \mathrm{y} \mathrm{n}^{\circ}{ }^{\circ} 11$, argentinos; y el n. ${ }^{\circ} 2$, de Chile, con dos piezas de artillería y 50 granaderos a caballo. Tres días después, la totalidad de la Expedición Libertadora había desembarcado en Pisco, noticia que consideró el virrey como la expresión del mayor peligro y a San Martín como sinónimo de anarquía, destrucción e infidencia. ${ }^{13}$ Finalmente, el 12 culminó el desembarco de las tropas y se estableció el cuartel general en Pisco, donde San Martín mandó se abracen algunas partidas de caballería sobre Caucato y Chincha "con el principal objeto de recolectar ganado y cabalgaduras" para facilitar las operaciones.

13 AGN.SU.GO_CO2_214,4564. 


\section{Cuadro 5. Fuerza naval de la Expedición Libertadora, según información del virrey Pezuela}

\begin{tabular}{|l|l|}
\hline \multicolumn{1}{|c|}{ Nombre } & \multicolumn{1}{|c|}{ Fuerza } \\
\hline $\begin{array}{l}\text { San Martín } \\
54 \text { cañones, bajo el mando del capitán Willkinson }\end{array}$ & 50 europeos y 150 chilenos \\
\hline $\begin{array}{l}\text { O'Higgins } \\
48 \text { cañones, bajo el mando del almirante Cochrane }\end{array}$ & 60 europeos y 210 chilenos \\
\hline $\begin{array}{l}\text { Lautaro } \\
42 \text { cañones, bajo el mando del capitán Guise }\end{array}$ & 70 europeos y 150 chilenos \\
\hline $\begin{array}{l}\text { Independencia } \\
26 \text { cañones, bajo el mando del capitán Forter }\end{array}$ & 60 europeos y 100 chilenos \\
\hline $\begin{array}{l}\text { Galvarino } \\
18 \text { cańones, bajo el mando del capitán Spry }\end{array}$ & 60 europeos y 40 chilenos \\
\hline $\begin{array}{l}\text { Araucano } \\
16 \text { cańones, bajo el mando del capitán Carter }\end{array}$ & 22 europeos y 30 chilenos \\
\hline $\begin{array}{l}\text { Moctezuma } \\
8 \text { cañones, destinado a llevar órdenes }\end{array}$ & Poca gente de tripulación \\
\hline Puyrredón & Sin información \\
\hline
\end{tabular}

Fuente: Pezuela (1947, pp. 756-757).

Tras su desembarco, San Martín dio inicio a una guerra de propaganda a favor de la independencia, acusando al virrey de ser quien había "imitado la conducta de su amo, con la esperanza de oponer una barrera al voto de la América y evitar que cooperes a su emancipación”. Así mismo, cuestionó los posibles efectos positivos que podría traer la Constitución de 1812, pues la consideraba nada más que un "código formulado a dos mil leguas de distancia, sin la intervención de nuestros representantes [americanos] y bajo el influjo del espíritu de partido que dominaba en las Cortes e la Isla de León”. Termina la proclama sentenciando la autoridad del virrey y reafirmando la importancia de su expedición: 
El último virrey del Perú hace esfuerzos para prolongar su decrépita autoridad, halagando vuestras esperanzas con una Constitución extranjera, que os defrauda el derecho representativo en que ella misma se funda, y que no tiene la menor analogía con vuestros intereses [...]. Yo vengo a acabar de poner término a esa época de dolor y humillación: este es el voto del Ejército Libertador, que tengo la gloria de mandar y que me ha acompañado siempre al campo de batalla, ansioso de sellar con su sangre la libertad del nuevo mundo. (CDIP, tomo IV, vol. 4, pp. 108-109)

Con estas afirmaciones, se puede pensar que San Martín no tenía intenciones de llevar a cabo las negociaciones de paz con las autoridades virreinales, pues las veía como decrépitas, mientras que consideraba que la Constitución gaditana había defraudado a los americanos. Un posible motivo para su aceptación pudo ser la necesidad de rearmarse y la búsqueda de un ambiente más favorable a la independencia entre la población mediante el envío de bandos y proclamas.

\section{Las negociaciones de paz}

El alzamiento de 1820 que llevó al retorno del constitucionalismo, como sostiene Martínez Riaza, "no fue obra de una masa indignada ni de un estado de opinión generalizado" (2011, p. 649), sino, más bien, de grupos muy concretos que estuvieron provistos de objetivos también muy concretos. Entre estos grupos, se encontraban los ideólogos y partidarios del régimen liberal-constitucional, gente de negocios, $y$, finalmente, parte del estamento militar. Sin embargo, existe una diferencia fundamental en relación con el liberalismo doceañista: en este caso, el rey ya no estaba cautivo, sino que se encontraba presente y dispuesto a ejercer sus prerrogativas en una realidad diferente a la del primer liberalismo, tanto en su dimensión peninsular como en el escenario americano.

De esta manera, y siguiendo las indicaciones enviadas desde Madrid, el virrey propuso a San Martín el cese de hostilida- 
des, pese a que, según sostenía, el Virreinato se encontraba militarmente preparado para repeler cualquier agresión y se encontraba dispuesto a "frustrar con honor de las armas del Rey cualesquiera designios hostiles [prefiriendo] en sumo grado los triunfos de la paz y de la razón a los laureles de la guerra”. ${ }^{14}$ Para el virrey Pezuela, la nueva situación política que vivían la monarquía espańola y el virreinato peruano podía frenar el avance de la independencia al obligar a San Martín a firmar un tratado de paz y, de esta forma, evitar el "continuo derramamiento de sangre" y la destrucción de Lima. No obstante, lo que en realidad buscaba el virrey era ganar tiempo, con la esperanza del arribo de refuerzos provenientes de España (Luqui, 2006, p. 338). ${ }^{15}$

En respuesta a la misiva enviada por el virrey, San Martín sostuvo que nada le era más grato "que el tratar siempre de proporcionar a los pueblos de América la mayor suma de prosperidad con la menor efusión de sangre". Continúa argumentando que, luego de los acontecimientos de Chacabuco y Maipú, el virrey ha podido observar "la consonancia [...] para que una transacción pacífica conciliase a todos los intereses"; concluye afirmando su disposición a escuchar las proposiciones del virrey relativas a estos objetivos, para lo que decide enviar diputados a la brevedad posible. Por su parte, el virrey manifestó que no dudaba de que los sentimientos de San Martín fuesen conformes con los que el rey y la nación apetecen, los cuales eran la reconciliación de españoles y americanos (CDIP, tomo XII, pp. 44-45 y CDIP, tomo XII, pp. 45-46).

14 AGN.D1_97,2209.

15 San Martín, por su parte, desde su llegada a Huaura, consideró importante contar con el apoyo de la intendencia de Trujillo. Para lograrlo, mantuvo comunicaciones con su intendente, el criollo limeño Bernardo de Tagle y Portocarrero, IV marqués de Torre Tagle. Al respecto, véase O’Phelan (2019, pp. 393-394). 
Pezuela esperaba un ataque inminente sobre la capital. No obstante, este no se produjo debido a que San Martín continuaba buscando la adhesión de la población a la causa independentista. Debido a esto, y para sorpresa de muchos, San Martín aceptó las propuestas del virrey y se dio inicio a las conversaciones de paz (Alvarado Luna, 2015b, p. 60; Peralta, 2010, p. 287; Anna, 2003, p. 219; y Pons Muzzo, 1999). Sin embargo, no todos estaban de acuerdo con estas medidas: tanto Cochrane como los generales realistas preferían un ataque directo que las negociaciones, lo cual terminó desatando nuevos conflictos al interior de ambos ejércitos. En este contexto, el 11 de setiembre, se dio inicio a las conversaciones y negociaciones de paz, las cuales se extendieron hasta el 4 de octubre.

Desde la primera entrevista en Miraflores, los diputados de San Martín, Tomás Guido y Juan García del Río, manifestaron que su objetivo era tratar directamente con el virrey; no obstante, los comisionados de este último, Hipólito Unanue, Dionisio Capaz y el conde de Villar de Fuentes, argumentaron la imposibilidad de su presencia, a causa de sus múltiples y recargadas ocupaciones al mando del Virreinato (CDIP, tomo XII, p. 46).

Por el lado virreinal, los comisionados del virrey Pezuela propusieron, como base para el arreglo de la situación americana, que se aceptara la Constitución de 1812 y que se hiciera el envío de diputados americanos a las Cortes. Sin embargo, esta proposición fue rechazada, como era de esperarse, debido a la proclama de San Martín, fechada el 8 de setiembre, en la cual, como ya hemos mencionado, cuestionaba los beneficios del liberalismo gaditano para los territorios americanos. Perplejo por esta primera negativa, los diputados del virrey propusieron tres puntos a sus contrapartes. Los diputados de San Martín aceptaron con algunas modificaciones, presentando una verdadera contraposición: se debía nombrar 
una comisión conciliadora y enviar diputados a Espańa; el Ejército Libertador debía evacuar Perú y trasladarse al margen izquierdo del Desaguadero, para ocupar las provincias de Potosí, Cochabamba, Chuquisaca y La Paz, mientras que el ejército realista en el Alto Perú se replegaría de la mencionada línea divisoria durante el armisticio. Pese a la tregua, se le comunicó al virrey Pezuela del avistamiento de naves "enemigas" en el puerto de Pisco (O’Phelan, 2019, pp. 401-403). ${ }^{16}$

El programa de la jura de la Constitución llevado a cabo el 15 se setiembre fue similar al anterior: cuatro tablados en la plaza Mayor, La Merced, la Inquisición y en Santa Ana con una comitiva de una compañía de Húsares montados por delante, seguidos por ocho sargentos de cada cuerpo, una compañía de Granaderos, los Tribunales y generales con el virrey, y las compañías de caballería y alabarderos. Pese a este despliegue, el virrey se lamentó de que

No se oyó un ¡Viva! ni la menor demostración de alegría hasta que en la Plaza de Santa Ana, el Oidor Osma tiró a la multitud de negros y zambos que seguían a la comparsa, un puñado de plata, y esto les avivó y gritaron con algunas vivas para ver si se les echaba más plata, pues ni esta gente ni los más principales ni de otras clases manifestaron ni regocijo ni repugnancia en el acto; parecía y lo creí así que todo les era indiferente. (Pezuela, 1947, p. 763)

La indiferencia, la preocupación y la creciente situación de inseguridad en la capital por la cercanía del ejército de San Martín, además de la falta de alimentos, el brote de epidemias y la negativa por parte de los jefes del ejército virreinal de respetar el armisticio, comenzaron a minar la autoridad del virrey. Es interesante notar que, el 17 del mismo mes, por la noche, el virrey anotó que, salvo la "novedad que causa un cambio de gobierno", no había ocurrido en el Virreinato "la

16 AGN.SU.GO_CO2_214,4564. 
menor inquietud", salvo la presentación de Valleumbroso, García Camba y Bazo "con otros muy pocos, capitaneando una multitud de negros y zambos con achas encendidas gritando: ¡Salga el virrey al balcón y viva la Constitución!” (Pezuela, 1947, p. 764). Las ofertas y contraofertas continuaron hasta el 30 de setiembre, día en que el mismo virrey Pezuela recibió a los comisionados independentistas en su casa de La Magdalena. En esta reunión, el virrey entregó las instrucciones incluidas en la real orden, mientras que los diputados de San Martín le comunicaron su plan de instaurar una monarquía constitucional en el Perú, a cuya cabeza se encontraría un miembro de la casa real espańola.

El 1. ${ }^{\text {ro }}$ de octubre, salieron de Miraflores los diputados de San Martín con las proposiciones de paz enviadas por los diputados del virrey a fin de que "cesen las calamidades de la guerra que ha afligido estas hermosas Provincias" (CDIP, tomo VI, vol. 3, p. 118). En primer lugar, se establecía que se evacuase Pisco, volviese la expedición a Chile, "el Ejército, reconociesen y jurasen la Constitución de la Monarquía española y quedasen mandando los mismos que están en el día a las órdenes del virrey de Lima, o en derechura si querían a las del Rey, y enviasen Diputados a la Corte". Como segundo punto, se propuso, en caso de que no se encuentre conveniente el punto anterior, se embarcasen a Pisco y volviesen a Chile, donde quedarían mandando sus ejércitos, "los mismos que tienen en el día, con total suspensión de hostilidades por mar y por tierra, hasta que diputados fuesen a Madrid [y] espusiesen sus quejas y pretensiones al Rey". Finalmente, y de manera reservada, se le ofreció a San Martín y a todo el ejército, conservar sus empleos y propiedades si accedían al primer artículo (Pezuela, 1947, p. 773; véase Martínez y Moreno 2014, pp. 107-114).

En una carta confidencial enviada a San Martín sobre el mismo tema, el virrey Pezuela sostuvo que "una mala paz (si 
entre nosotros puede ser mala por ningún aspecto), es mejor que la guerra más feroz: demos pues el día suspirado a unos habitantes que tanto lo apetecen" (CDIP, tomo VI, vol. 3, p. 119). Todos los intentos por conseguir la paz con los independentistas terminaron en fracaso. En la noche del 5 de octubre, el virrey recibió la contestación de San Martín, en la cual "se negaba absolutamente a las proposiciones" (Pezuela, 1947, p. 777).

Las críticas al virrey Pezuela no se hicieron esperar. García Camba consideró que el ejército de Lima "no podía razonablemente prometer una lisonjera esperanza de defensa si llegaba pronto el caso de abrir con él una campaña activa”. Esto se evidencia en la información proporcionada por los jefes militares sobre cantidad de tropas ubicadas en Lima y el Callao, los cuales hacían un total de 9,472 soldados (García Camba, 1846, p. 333 y Pezuela, 1947, p. 777).

\section{Conclusiones}

Para los independentistas, el dominio del mar del Sur era fundamental para asegurar el desarrollo y la consolidación de su movimiento, mientras que, para el Gobierno virreinal del Perú, mantener el control de las costas del Virreinato le permitiría movilizar sus tropas y recibir, sin mayores contratiempos, cualquier apoyo proveniente de la metrópoli. Para Chile, en especial, al ser un país netamente costero, el dominio del Pacífico significaría la seguridad de sus fronteras y la posibilidad, en años venideros, de ejercer un predominio comercial en la región. Debido a esto, la atención de San Martín de invadir el Perú se concentró en la guerra marítima y no tanto en la terrestre, como se había dado hasta ese momento, y la formación de una escuadra era el único medio para lograrlo.

Fueron dos ańos en los que el virrey Pezuela tuvo que enfrentar la amenaza de la invasión del ejército de San Martín 
hasta que finalmente zarpó la expedición y desembarcó en Pisco en agosto de 1820 . El primer accionar del virrey tras conocerse la pérdida de Chile en abril de 1818 fue considerarla una noticia exagerada; sin embargo, optó por movilizar diversos batallones hacia Lima, además de buscar las fuerzas militares dentro del Virreinato y préstamos económicos para el sostenimiento de la defensa de la capital. Estos planes defensivos a lo largo de 1818 ante los rumores de la preparación y próxima partida de una expedición a las costas virreinales no solo generaron temor y ansiedad en la población, sino que también dieron inicio a los cuestionamientos a la autoridad y capacidad del virrey.

Con los bloqueos y ataques llevados a cabo por Thomas Cochrane, las autoridades virreinales -especialmente el virreyidentificaron como una certeza el peligro que corría Lima. Como hemos visto, incluso durante el bloqueo marítimo del Callao, los rumores referentes a la preparación de la expedición continuaban llegando al Virreinato. Con casi con 7,000 efectivos militares en Lima, contener cualquier ataque a la capital era muy factible. Pese a esto, el principal objetivo de la expedición de Cochrane se había concretado: reconocer las costas y asegurarse -según él mismo- de la intención de los peruanos por emanciparse.

Los nuevos ataques y bloqueos comandados por Cochrane a fines de 1819 obligaron al virrey a continuar solicitando el envío de armamento, alimento y efectivos militares a Lima. Este afán por defender la capital se debe a que, a ojos del virrey y de muchos militares formados en el siglo XVIII -quienes no habían participado en las guerras napoleónicas-, el centro del poder no podía caer; de suceder, se perdería todo el territorio. Esta percepción terminó siendo errada, tal como se vio luego de la entrada de San Martín en julio de 1821 y del retiro del virrey La Serna al Cuzco, lo que prolongó la guerra por tres años más. 
Los primeros meses de 1820 truncaron los planes defensivos del virrey, pues los tan ansiados refuerzos provenientes de España se sublevaron, se reinstauró el sistema constitucional en la península y se obligó, por decreto, a que se entablasen negociaciones de paz con los "sublevados". Incluso durante estos meses y pese a los cada vez más frecuentes rumores, el virrey Pezuela continuó escéptico frente al arribo de la expedición de Chile. Esta visión es comprensible, pues habían pasado casi dos años y no se había concretado el tan anunciado ataque militar.

Empeñado en mantener el flujo comercial en las costas virreinales, Pezuela decretó el libre comercio con las naciones extranjeras, lo que despertó el rechazo del Tribunal del Consulado. Esta fue la única forma que encontró el virrey de sostener, con provisiones y armamento, a las fuerzas militares que se encontraban tanto en Lima como en el resto de la costa virreinal.

Con el arribo de la Expedición Libertadora y su desembarco en Pisco, San Martín dio inicio a una campaña propagandística para deslegitimar la ya dañada la autoridad del virrey. Este, por su parte, remitió una serie de proclamas y bandos al ejército y habitantes del Virreinato, en los que desacreditaba las intenciones de San Martín y enfatizaba que, con él, llegaba la anarquía. Pese a esto, el virrey, siguiendo las instrucciones de Madrid, propuso a San Martín negociaciones de paz entre sus comisionados.

Como era de esperarse, las negociaciones no llegaron a buen puerto. El virrey no reconocería la independencia del Perú; San Martín no aceptaría que el Perú continuase en manos de la metrópoli mediante la jura de la Constitución española y que no se reconociese la independencia de las Provincias Unidas del Río de la Plata y de Chile. Este nuevo fracaso del virrey Pezuela ocasionó que los jefes y generales realistas 
continuasen dudando de su capacidad, así como de su real predisposición de atacar a las fuerzas de San Martín.

Recibido: 05 de agosto de 2020

Aprobado: 10 de noviembre de 2020

\section{Fuentes de Archivo}

Archivo General de la Nación del Perú

Superior Gobierno

GO_BI_BI3_120,288

GO_CO2_214,4497

GO_CO2_214,4543

GO_CO2_214,4564

D1_97,2209

\section{Bibliografía}

Albi de la Cuesta, J.

(2009) El último virrey. Ollero y Ramos.

Anna, T. E.

(2003) La caída del Gobierno español en el Perú. Instituto de Estudios Peruanos.

Alvarado Luna, P.

172

(2020) Virreyes en armas. Abascal, Pezuela y La Serna: la lucha contrarrevolucionaria desde el virreinato del Perú (1808-1826). Instituto Riva-Agüero

Alvarado Luna, P.

(2017a) "Los virreyes Abascal y Pezuela frente Chile: políticas contrarrevolucionarias del virreinato del Perú, 18101818". En C. Rosas y M. Chust (Eds.), El Perú en revolución. Independencia y guerra: un proceso, 17801826 (pp. 249-264). Universitat Jaume I. 
Alvarado Luna, P.

(2017b) En defensa del imperio. Políticas contrarrevolucionarias de los virreyes del Perú José Fernando de Abascal, Joaquin de la Pezuela y José de la Serna frente a la independencia hispanoamericana, 1809-1824. (Tesis para optar el grado de magíster en Historia). Pontificia Universidad Católica de Perú, Escuela de Posgrado, Lima.

Alvarado Luna, $\mathrm{P}$.

(2015a) "La reconquista imposible: planes político-militares del virrey Pezuela frente a la independencia de Chile, 1817-1818". Artificios. Revista colombiana de estudiantes de Historia (3), 108-131.

Alvarado Luna, $\mathrm{P}$.

(2015b) "El virrey y el general: discrepancias político-militares en el ejército realista, 1816-1821”. En. S. O'Phelan (Ed.). La Quinta de los Libertadores [Catálogo]. (pp. 47-62). Ministerio de Cultura del Perú y Museo Nacional de Arqueología, Antropología e Historia del Perú.

Alvarado Luna, $P$.

(2014) "En Lima se estrellaron siempre sus avanzados proyectos": el virrey Joaquin de la Pezuela frente a la independencia del Perú, 1816-1820". (Tesis para optar el grado de licenciado en Historia). Pontificia Universidad Católica de Perú, Facultad de Letras y Ciencias Humanas, Lima.

Barros Arana, D.

(1897) Historia general de Chile. Tomo XIV. Rafael Jover Editor.

Basadre Grohmann, J.

(1973) El azar en la historia y sus límites. P. L. Villanueva. 
Bulnes, G.

(1887-1888) Historia de la Expedición Libertadora del Perú (18171822). Tomo I. Rafael Jover Editor.

Cochrane, $\mathrm{T}$.

(1910) Memorias de lord Cochrane. Editorial América.

Colección Documental de la Independencia del Perú (CDIP).

(1971-76) 86 volúmenes. Comisión Nacional del Sesquicentenario de la Independencia del Perú.

Collier, S.

(2012) Ideas y politica de la independencia chilena, 18081833. Fondo de Cultura Económica.

Collier, S.

(2004)

A History of Chile, 1808-2008. Cambridge University Press.

Costeloe, $\mathrm{M}$.

(2010) La respuesta a la independencia. La España imperial y las revoluciones, 1810-1840. Fondo de Cultura Económica.

Delameau, J.

(1985) Angst im Abendland. Die Geschichte kollektiver Ängste im Europa des 14. bis 18. Jahrhunderts. Rowohlt Taschenbuch Verlag.

Espejo, G.

174 (1978) Apuntes históricos sobre la Expedición Libertadora del Perú, 1820. Instituto Nacional Sanmartiniano.

Fisher, J.

(2000) El Perú borbónico, 1750-1824. Instituto de Estudios Peruanos. 
García Camba, A.

(1846) Memorias para la historia de las armas españolas en el Perú, 1809-1825, vols. 1 y 2. Sociedad Tipográfica de Hortelano y Compañía.

Jocelyn-Holt, A.

(2012) La independencia de Chile. Tradición, modernización $y$ mito. Debolsillo.

Luqui, J.

(2006) Por el rey, la fe y la patria. El ejército realista del Perú en la independencia sudamericana. 1810-1825. Colección ADALID.

Martínez Riaza, A.

(2016) “'Donde dije digo...'. El Gobierno del Perú y el cambio político en España, 1820-1833”. En E. García, I. Frasquet y C. García Monerris (Eds.), Cuando todo era posible: liberalismo y antiliberalismo en España e Hispanoamérica (1740-1842) (pp. 95-126). Silex.

Martínez Riaza, A.

(2014) "Todos eran realistas. Liberalismo y absolutismo en el Gobierno del virreinato del Perú, 1820-1824”. En I. Álvarez y J. Sánchez (Coords.), Visiones y revisiones de la independencia americana. Realismo/pensamiento conservador: ¿una identificación equivocada? (pp. 121143). Universidad de Salamanca.

Martínez Riaza, A. y Moreno Cebrián, A.

(2014) "La conciliación imposible. Las negociaciones entre espańoles y americanos en la independencia del Perú, 1820-1824”. En A. Martínez (Ed.), La independencia inconcebible. España y la "pérdida" del Perú (1820-1824) (pp. 99-212). Fondo Editorial de la Pontificia Universidad Católica del Perú e Instituto Riva-Agüero. 
Mazzeo de Vivó, C.

(2005) "El miedo a la revolución de independencia del Perú, 1818-1824”. En C. Rosas (Ed.), El miedo en el Perú, siglos XVI al XX (pp. 167-184). Fondo Editorial de la Pontificia Universidad Católica del Perú y Sidea.

Miller, J. (Ed.).

(1910) Memorias del general Guillermo Miller: al servicio de la República del Perú. Librería de Victoriano Suárez.

O'Phelan Godoy, S.

(2019) "El norte patriota y el sur realista. La división territorial del Perú en el contexto de la Independencia”. En S. O’Phelan y A. C. Ibarra (Comp.), Territorialidad y poder regional en las independencias de México y Perú (pp. 389-428). Fondo Editoral del Congreso del Perú.

O'Phelan Godoy, S.

(2010a) San Martín y su paso por el Perú. Fondo Editorial del Congreso del Perú.

O'Phelan Godoy, S.

(2010b) Bernardo O'Higgins y sus estancias en el Perú. Fondo Editorial del Congreso del Perú.

Peralta Ruiz, V.

(2010) La independencia y la cultura politica peruana (18081821). Instituto de Estudios Peruanos y Fundación M. J. Bustamante de la Fuente.

Pezuela, J. de la.

(1947) Memoria de Gobierno. Vicente Rodríguez Casado y Guillermo (Eds.). Lohmann Villena. Escuela de Estudios Hispanoamericanos.

Pons Muzzo, G.

(1999) Las Conferencias de Miraflores y Punchauca. Instituto Sanmartiniano del Perú. 
Puente Candamo, J. A. de la.

(1977) Historia maritima del Perú. La Independencia. Tomo $\mathrm{V}$, vol. 1. Instituto de Estudios Histórico-Militares del Perú.

Puente Candamo, J. A. de la.

(1971) Notas sobre la causa de la independencia del Perú. Talleres Gráficos P. L. Villanueva.

Puente Candamo, J. A. de la.

(1948) San Martín y el Perú. Planteamiento doctrinario. Editorial Lumen S. A.

Puente Brunke, J. de la.

(2012)

"'Todo fue atolondramiento, todo confusión'. Los militares realistas en la guerra de independencia del Perú y sus desavenencias". En C. McEvoy, M. Novoa y E. Palti (Eds.), En el nudo del imperio. Independencia y democracia en el Perú (pp. 187-206). Instituto de Estudios Peruanos e Instituto Francés de Estudios Andinos.

Puente Brunke, J. de la.

(1998) "El virrey Pezuela frente al proceso de la independencia peruana”. En H. López Martínez (Ed.), Homenaje a Don Aurelio Miró Quesada Sosa. Academia Nacional de la Historia y Consorcio de Universidades.

Rosas Lauro, C.

(2005) "El miedo a la revolución. Rumores y temores desatados por la Revolución francesa en el Perú, 17901800". En C. Rosas (Ed.), El miedo en el Perú, siglos $X V I$ al XX (pp. 139-166). Fondo Editorial de la Pontificia Universidad Católica del Perú y Sidea.

Rosas Moscoso, F.

(2005) "El miedo en la historia: lineamientos generales para su estudio". En: El miedo en el Perú, siglos XVI al XX. C. Rosas (Ed.), El miedo en el Perú, siglos XVI al XX 
(pp. 23-32). Fondo Editorial de la Pontificia Universidad Católica del Perú y Sidea.

Valdés, J.

(1894) Causas que motivaron la pérdida del Perú. Imprenta de la viuda de Minuesa de los Ríos. 